\title{
Assessment of the Soil Buffer Capacity in the Sea of Azov Basin Under Heavy Metal Pollution
}

\section{Tatiana Minkina, Dina Nevidomskaya, Aleksey Sherbakov, Victor Chaplygin, Yurii Litvinov, Natalia Kravtsova, Dmitry Bren, and Ilia Lobzenko}

Southern Federal University, Rostov-on-Don, Russia

\section{ORCID}

Tatiana Minkina; 0000-0003-3022-0883

Dina Nevidomskaya; 0000-0002-0138-4443

Corresponding Author: Tatiana Minkina; email: tminkina@mail.ru

\section{Dates}

Published 13 January 2022

Publishing services provided by Knowledge

(c) Tatiana Minkina et al. This article is distributed under the terms of the

Attribution License, which

permits unrestricted use and redistribution provided that the original author and source are credited.

Selection and Peer-review unde the responsibility of the 8th Scientific and Practical Conference Conference Committee.

\section{G OPEN ACCESS}

Abstract. Heavy metals (HM) are among the most hazardous soil pollutants. The intensity of accumulation and distribution of $\mathrm{HM}$ in soils directly depends on the ecological conditions of pedogenesis and its buffering properties. At the same time, a significant accumulation of $\mathrm{HM}$ in the soil as a result of anthropogenic impacts reduces the buffering capacity of the soil and its resistance to pollution. The purpose of this work was to assess the buffering capacity of soils to HM pollution in the Don River delta and the coast of the Taganrog Bay of the Sea of Azov undergoing the great anthropogenic impact. The buffer capacity of experimental soils was carried out using the Il'in's method (1995), based on the calculation of the inactivation ability of soils: organic matter, clay fraction (particle size $<0.01 \mathrm{~mm}$ ), carbonates, sesquioxides, and $\mathrm{pH}$. The content of HM was compared with soil Clarke and the maximum permissible concentration of $\mathrm{HM}$ in soils accepted in the Russian Federation. It was found that the experimental soils could be ordered by buffer capacity value as following (in decreasing order): haplic chernozem $\geq$ alluvial-meadow light loamy $\geq$ solonchak $>$ alluvial-meadow sandy and sandy loamy $>$ sandy primitive soil $\geq$ stratified alluvial soil.

Keywords: trace elements, contamination, impact territories

Chemical pollution of the environment is one of the modern global problems. Soil accumulates about $95 \%$ of emissions in various chemical forms. Therefore, soil pollution affects whole ecosystem. Technogenic pollution changes the physical, chemical, and biological properties of soils [1-5] that results in decrease of soil buffer capacity, a shift of soil balance, and an increase of ecologically negative consequences for biosphere in general $[1,4,6]$. It is known that heavy metals $(\mathrm{HM})$ are the most hazardous substances revealing carcinogenic, mutagenic, and toxic effects in living organisms [6]. The goal of this work is to assess the buffering capacity of soils to HM pollution in the Don River delta and the coast of the Taganrog Bay of the Sea of Azov undergoing the great anthropogenic impact.

In 2020, the comprehensive monitoring studies covering a significant territory including the floodplain, the Don River delta, estuarine areas of small rivers and the Russian 
part of the coast of the Taganrog Bay of the Sea of Azov were carried out to assess the buffering capacity of soils, the patterns of accumulation and distribution of HMs within floodplain, delta and coastal landscapes (Figure 1). The study area is characterized by favorable natural conditions and is a unique area. However, this territory is subjected to active technogenic impact in present time. Priority attention was paid to the territories undergoing the great anthropogenic pollution, for example, impact zones with industrial enterprises, roads, settlements, a seaport with terminals, etc.

The soil cover in the study area is represented by zonal soils such as Haplic Chernozem and intrazonal soils: Alluvial-meadow light loamy, Stratified alluvial soil, Sandy primitive soil, and Solonchak. According WRB (2014) these soils are named Haplic Calcic Chernozem Loamic, Calcic Fluvisol Humic Loamic, Solonchak Loamic, Arenosol, Fluvic Arenosol.

Sampling of soil at a depth $0-20 \mathrm{~cm}$ was carried out from each monitoring site. The level of soil contamination was determined by the total content of $\mathrm{Mn}, \mathrm{Cr}, \mathrm{Ni}, \mathrm{Cu}, \mathrm{Zn}, \mathrm{Pb}$, and $\mathrm{Cd}$ in soils using the $\mathrm{X}$-ray fluorescence. The physical and chemical properties were determined as following: particle size distribution by pipette method (pyrophosphate sample preparation according to GOST 12536-79); organic matter $\left(\mathrm{C}_{\text {org }}\right)$ content by Tyurin method, echangable bases of $\mathrm{Ca}^{2+}$ and $\mathrm{Mg}^{2+}$ by complexometric method, carbonate content by the Kudrin's method, and $\mathrm{pH}_{\text {water }}$ was measured potentiometrically [7]. The chemical (compound) composition of the mineral part of soils was determined by measuring of the mass fraction of oxides of elements in powder samples by X-ray fluorescence analysis using a MAKC-GV spectroscan.

The buffer capacity was evaluated according to Il'in's method [8] based on determination of inactivating ability of soil properties: organic matter $\left(C_{\text {org }}\right)$, physical clay $(\mathbb{Q}$ of fine dispersed soil fractions $<0.01 \mathrm{~mm})$, carbonates $\left(\mathrm{CO}_{3}{ }^{2-}\right)$, sesquioxides $\left(\mathrm{R}_{2} \mathrm{O}_{3}\right)$, and $\mathrm{pH}$. The content of HM was compared with soil Clarke [9] and the maximum permissible concentration of HMs in soils accepted in the Russian Federation [11].

The characteristics of some physical and chemical properties of the main types of soils sampled from the monitoring sites are shown in Table 1.

The study results show that the examined soil types are characterized by weak alkaline reaction or strong alkaline reaction of media (7.3-8.2), the content of $\mathrm{C}_{\text {org }}$ is varying and depends on soil type $(0.1 \%$ for sandy primitive soil; $0.4-1.3 \%$ for Stratified alluvial and Alluvial-meadow soils; $0.8 \%$ for Solonchak; and $2.8 \%$ for chernozem). Soil particle size distribution is changing from sandy and sandy loamy in Sandy primitive soils and Stratified alluvial soils (fraction content $<0.001-2.9 \%$ and fraction $<0.01-5.3 \%$ ) and 


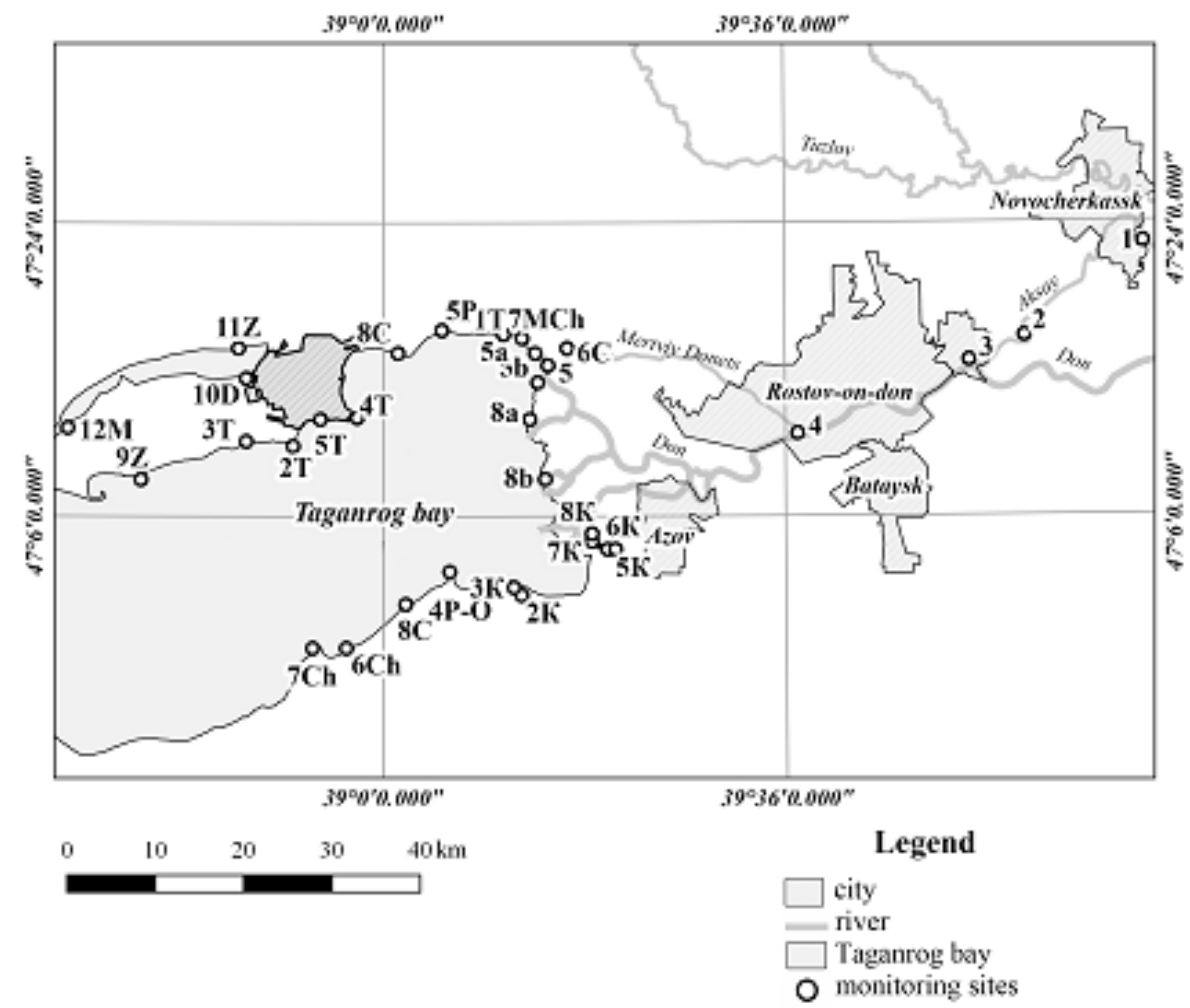

Figure 1: Location of monitoring sites in the Don River delta and the coast of the Taganrog Bay (Sea of Azov).

light loamy in Alluvial-meadow soils (fraction content $<0.001-13.9 \%$ and fraction $<0.01-$ 26.4 \%) until light loamy and middle loamy in Solonchak (fraction content $<0.001-20.2$ $\%$ and fraction $<0.01-36.1 \%$ ) and Haplic Chernozem (fraction content $<0.001-25.1 \%$ and fraction $<0.01-38.6 \%)$. The high content of carbonates on the surface of Stratified alluvial soils and Alluvial-meadow soils is associated with the presence of biogenic calcite in the silted horizons (Table 1).

Soils with light granulometric composition contains higher amount of $\mathrm{SiO}_{2}$ and $\mathrm{CaO}$ due to higher content of biogenic calcite in the coastal area [12]. In contrast to light sandy and Stratified alluvial soil, a drastically decrease of the content of $\mathrm{SiO}_{2}$ and an increase in sesquioxides $\mathrm{Al}_{2} \mathrm{O}_{3}$ and $\mathrm{Fe}_{2} \mathrm{O}_{3}$ were observed in the distribution of macronutrients in solonchak. Light loamy Alluvial-meadow soils and Haplic Chernozem are distinguished by sufficient amounts of $\mathrm{R}_{2} \mathrm{O}_{3}$ and other oxides containing the primary nutrients such as $\mathrm{CaO}, \mathrm{MgO}$, and $\mathrm{K}_{2} \mathrm{O}$.

The complex of physical and chemical parameters directly determines the protective function of soils. To evaluate these functions, we have estimated the buffer capacity of soils to HM pollution. The ecological conditions of pedogenesis and buffer properties 
TABLE 1: Physicochemical properties of the main soil types from monitoring sites in the Don River delta and the coasts of the Taganrog Bay (Sea of Azov) at a depth 0-20 cm.

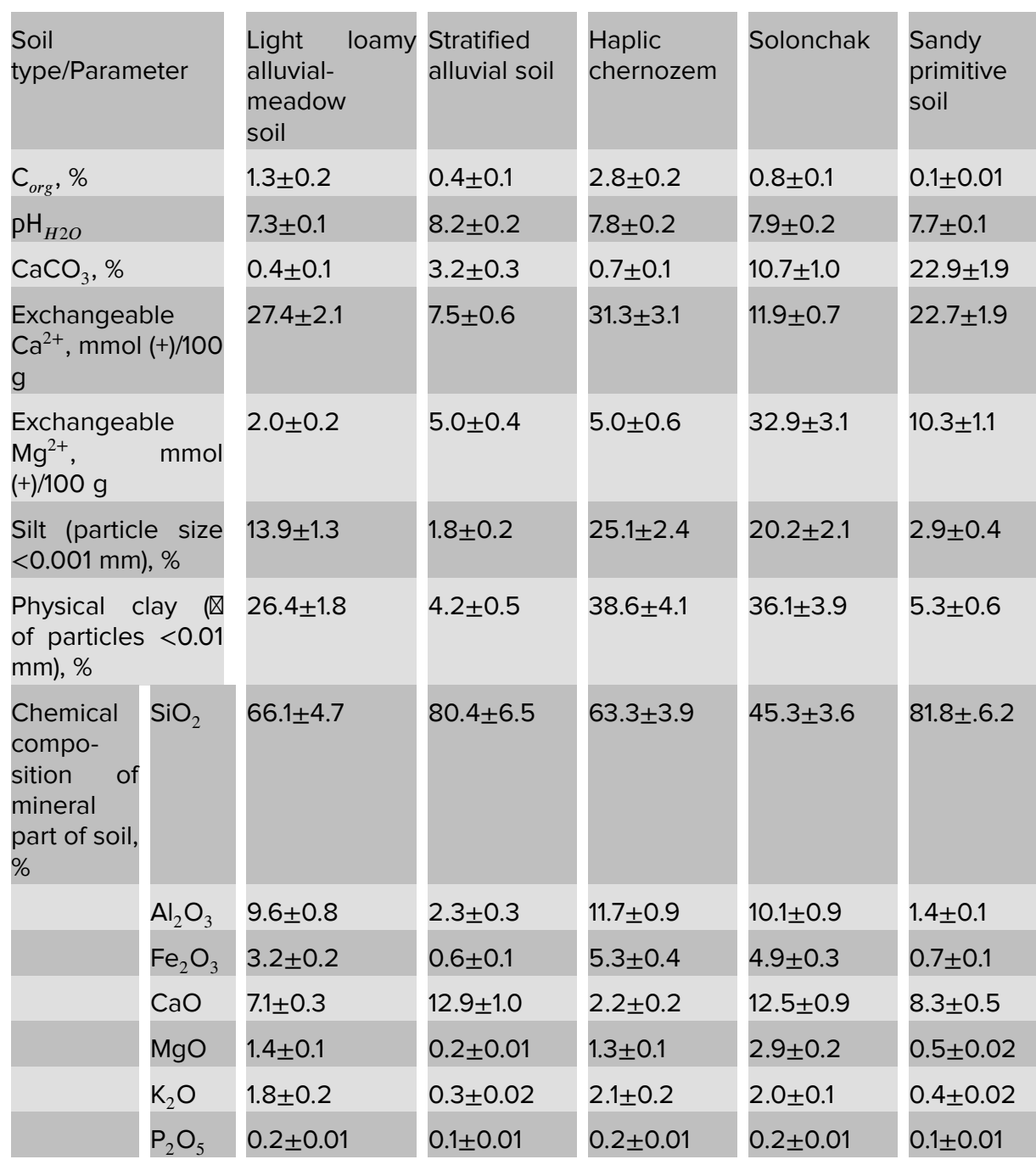

of soils directly affect the intensity of accumulation and distribution of HM in soils. High content of humus and silty particles in soil stimulate active accumulation of metals in Haplic Chernozem, Solonchak, Alluvial-meadow loamy soil types (Table 2).

Hydrogenic accumulation due to the influx of solid run-off is important process for sandy loamy and sandy Alluvial-meadow soils and Stratified alluvial soils [13]. However, the content of HMs in this soil is low due to the weak humification, the low content of absorbed cations, silty particles, and other factors.

Figure 2 shows that the effect of $\mathrm{pH}$ and sesquioxides is almost constant in all soil types. According to the gradation of the buffer capacity of soils polluted by HMs, stratified alluvial soil (monitoring sites nos. 2T, 3T, 5) and sandy loamy alluvial-meadow soils (site nos. 4P-O, 8b) are characterized with average degree of buffer capacity, but Haplic Chernozem revealed the maximum value (site no. $1 \mathrm{~K}$ ). 
TABle 2: Total content $\mathrm{Mn}, \mathrm{Cr}, \mathrm{Cu}, \mathrm{Zn}, \mathrm{Pb}, \mathrm{Cd}$ and $\mathrm{Ni}$ in soils from monitoring sites in the Don River delta and the coasts of the Taganrog Bay (Sea of Azov) at a depth $0-20 \mathrm{~cm}, \mathrm{mg} / \mathrm{kg}$.

\begin{tabular}{|c|c|c|c|c|c|c|}
\hline $\begin{array}{l}\text { Metals } \\
\text { type }\end{array}$ & $\begin{array}{l}\text { sLight loamy } \\
\text { alluvial-meadow } \\
\text { soil }\end{array}$ & $\begin{array}{l}\text { Stratified } \\
\text { alluvial soil }\end{array}$ & $\begin{array}{l}\text { Haplic } \\
\text { Chernozem }\end{array}$ & Solonchak & $\begin{array}{l}\text { Sandy primi- } \\
\text { tive soil }\end{array}$ & $\begin{array}{l}\text { Soil Clarke } \\
\text { /MPC }\end{array}$ \\
\hline $\mathrm{Mn}$ & $780 \pm 56$ & $552 \pm 39$ & $426 \pm 51$ & $1243 \pm 97$ & $532 \pm 34$ & $1000 /-$ \\
\hline $\mathrm{Cr}$ & $104.8 \pm 7.3$ & $89.5 \pm 5.9$ & $123.5 \pm 8.5$ & $103.6 \pm 6.9$ & $37.8 \pm 2.3$ & $83 / 90$ \\
\hline $\mathrm{Cu}$ & $41.1 \pm 2.6$ & $29.0 \pm 1.5$ & $55.2 \pm 3.4$ & $63.1 \pm 3.9$ & $3.9 \pm 0.3$ & $47 / 55$ \\
\hline $\mathrm{Zn}$ & $202.8^{*} \pm 18.4$ & $74.1 \pm 5.8$ & $85.2 \pm 5.7$ & $103.8 \pm 9.5$ & $8.9 \pm 0.6$ & $83 / 100$ \\
\hline $\mathrm{Pb}$ & $43.7 \pm 1.9$ & $19.7 \pm 0.8$ & $31.8 \pm 2.4$ & $39.6 \pm 2.0$ & $11.9 \pm 0.7$ & $16 / 32$ \\
\hline $\mathrm{Cd}$ & $0.3 \pm 0.01$ & $0.4 \pm 0.02$ & $0.6 \pm 0.03$ & $0.6 \pm 0.03$ & $0.2 \pm 0.01$ & $0.13 / 0.5$ \\
\hline $\mathrm{Ni}$ & $31.5 \pm 2.6$ & $39.6 \pm 1.8$ & $65.0 \pm 4.7$ & $64.5 \pm 2.9$ & $27.8 \pm 1.1$ & $58 / 85$ \\
\hline \multicolumn{7}{|c|}{ *higher soil Clarke [9] and MPC [10-11]. } \\
\hline
\end{tabular}

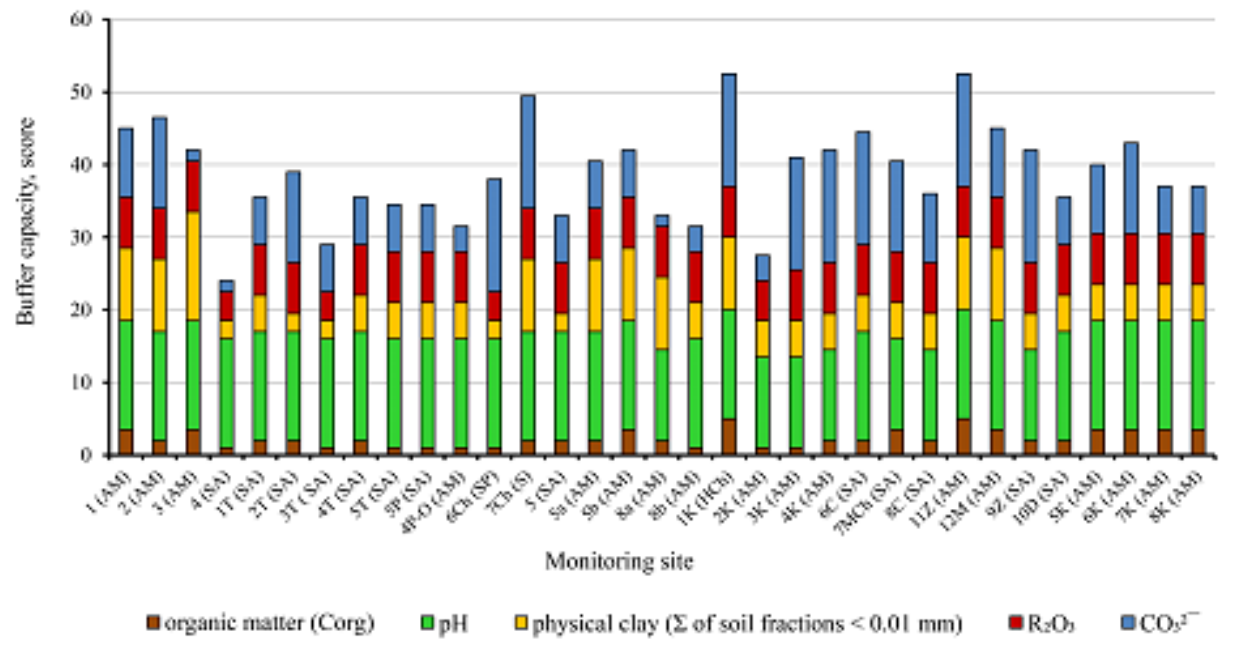

Figure 2: Buffer capacity of soils on the monitoring sites in the Don River delta and the coasts of the Taganrog Bay (Sea of Azov) at a depth 0-20 cm under HM pollution: (AM) Alluvial-meadow soil; (SA) Stratified alluvial soil; (S) Solonchak; (HCh) Haplic Chernozem; (SP) Sandy primitive soil.

Thus, the resistance of various soil types regards to the accumulation and distribution of $\mathrm{HM}$ is closely related to the protective function of soils and affected by the edaphic factor and the anthropogenic pollution of aquatic landscapes. According to buffer capacity of soils polluted with HMs, all the studied soils can be positioned as following (in descending order): Haplic Chernozem meadow loamy $\geq$ Alluvial-meadow light loamy $\geq$ Solonchak meadow loamy $>$ Alluvial-meadow sandy and sandy loamy $>$ Sandy primitive soil $\geq$ Stratified alluvial soil.

This study is financially supported by the Russian Science Foundation, project no. 20-14-00317. 


\section{References}

[1] Sparks DL. Environmental soil chemistry. $2^{\text {nd }}$ edition. USA: Academic Press; 2003.

[2] Minkina TM, Fedorov YA, Nevidomskaya DG, Mandzhieva SS, Kozlova MN. Specific features of content and mobility of heavy metals in soils of floodplain of the Don River. Arid Ecosystem. 2016;6(1):70-79.

[3] Minkina TM, Fedorov YA, Nevidomskaya DG, Pol'shina TN, Mandzhieva SS, Chaplygin VA. (2017). Heavy metals in soils and plants of the Don River estuary and the Taganrog Bay Coast. Eurasian Soil Science. 2017;50(9):1033-1047.

[4] Minkina TM, Shvydkaya NV, Alekseenko VA, Nevidomskaya DG. Soils of geochemical landscapes of the lower Don River and their ecological characteristics. Rostov-onDon: Southern Federal University; 2018.

[5] Minkina TM, Nevidomskaya DG, Pol'shina TN et al. Heavy metals in the soil-plant system of the Don River estuarine region and the Taganrog Bay coast. Journal of Soils and Sediments. 2017;17(5):1474-1491.

[6] Violante A, Krishnamurti GSR, Pigna M. Factors affecting the sorption-desorption of trace elements in soil environments. Biophysico-chemical processes of heavy metals and metalloids in soil environments. Hoboken: Wiley; 2008.

[7] Vorob'eva LA. Theory and practice of chemical analysis of soils. Moscow: GEOS; 2006.

[8] Il'in VB. Evaluation of buffer capacity of soils in conditions of heavy metal pollution. Agrokhimiya. 1995;10:109-113.

[9] Vinogradov AP. Geochemistry of rare and dispersed chemical elements in solis. Moscow: Academy of Sciences of USSR; 1957.

[10] Maximum permissible concentrations (MPC) of chemical substances in soil, approved by the order of the State Committee on Natural Resources of USSR No. 02-2333 on December 10, 1990.

[11] Methodological Recommendations MU 2.1.7.730-99. Hygienic assessment of soil quality in urban territories, Approved by the Chief Sanitary Physician of the Russian Federation. 1999.

[12] Khrustalev YP. Geochemistry of sedimentogenesis in the Sea of Azov. Apatity: Kola Scientific Center, Russian Academy of Science; 1999.

[13] Klenkin AA, Korpakova IG, Pavlenko LF, Temerdashev ZA. Ecosystem of the Sea of Azov: Anthropogenic pollution. Krasnodar: Azov Scientific Research Institute of Fisheries; 2007. 
[14] World Reference Base for Soil Resources 2014. International soil classification system for naming soils and creating legends for soil maps. World Soil Resources Reports, no. 106. Rome: FAO; 214. 